\title{
COMMUNITY CONTRIBUTIONS TO A FHU TEAM WORK
}

\author{
Maria José Sanches Marin ${ }^{1}$ \\ Luciana Rocha de Oliveira ${ }^{2}$ \\ Mércia Ilias ${ }^{3}$ \\ Elza de Fátima Ribeiro Higa ${ }^{1}$
}

Marin MJS, Oliveira LR, Ilias M, Higa EFR. Community contributions to a FHU team work. Rev Latino-am Enfermagem 2007 novembro-dezembro; 15(6):1065-71.

Considering the importance of people participating in the construction of new health models, this study aimed to characterize and analyze contributions brought by community to health actions carried out in a Family Health Unit. It is a documentary analysis based on the records of 24 monthly meetings between the team and community. After reading the records, subject was divided into four themes: material and human resources, availability to secondary level health services, community adherence to the unit activities, health promotion and disease prevention. Discussions opened a wide perspective on health and stimulated co-responsibility, stronger links and information exchanging. Nevertheless, there is a need to improve community effective participation in the co-management of the health system.

DESCRIPTORES: family health program; community participation; public health

\section{LAS CONTRIBUCIONES DE LA COMUNIDAD PARA EL TRABAJO DEL EQUIPO DE UN PSF}

Considerando la relevancia de la participación de la población en la construcción de nuevos modelos de salud, el presente estudio propone caracterizar y analizar las contribuciones de la participación de la comunidad en las acciones de salud de una Unidad de Salud de la Familia. Se trata de un estudio de análisis documentario, basado en actas de 24 reuniones mensuales del equipo con la comunidad. Después de la lectura de los registros, los asuntos fueran clasificados en cuatro temáticas: recursos materiales y humanos, accesos a los servicios de salud de nivel secundario, adherencia de la comunidad a las actividades ofrecidas por la unidad y promoción de la salud y prevención de enfermedades. Verificó-se que las discusiones destacaron una visión íntegra de la salud e hicieron posible la co-responsabilidad, fortalecimiento del vínculo y cambio de información. Todavía es necesario avanzar para obtener la efectiva participación de la comunidad en la cogestión del sistema de salud.

DESCRIPTORES: programa salud de la familia; participación comunitaria; salud pública

\section{AS CONTRIBUIÇÕES DA COMUNIDADE PARA O TRABALHO DA EQUIPE DE UM PSF}

Considerando a relevância da participação popular na construção de novos modelos de saúde, o presente estudo propõe-se a verificar as contribuições dessa participação nas ações de saúde de uma Unidade de Saúde da Família. Trata-se de estudo de análise documental, a partir de atas de 24 reuniões mensais da equipe com a comunidade. Após a leitura dos registros, os assuntos discutidos foram agrupados em quatro temáticas: recursos materiais e humanos, acesso aos serviços de saúde de maior complexidade, adesão da comunidade às atividades oferecidas pela unidade e promoção da saúde e prevenção de doenças. Constata-se que, embora as discussões vislumbrem a visão integral da saúde e possibilitem co-responsabilidade, fortalecimento do vínculo e troca de informação, ainda é necessário maior avanço para se obter a efetiva participação da comunidade na co-gestão do sistema de saúde.

DESCRITORES: programa saúde da família; participação comunitária; saúde pública

${ }^{1}$ RN, PhD in Nursing, Professor; ${ }^{2}$ RN, Family Health Program at Marília, Brazil, Specialist in Family Health, Colaborator Professor; ${ }^{3}$ Physician, Master in Public Health, Professor. Medical School at Marília, Brazil 


\section{INTRODUCTION}

Community participation is a movement that has been encouraged as a strategy to face health problems, thus achieving greater political awareness and sharing the responsibilities and information, in the attempt to improve people's autonomy and quality of life.

Citizens' participation in the public management of health has been articulated since the National Sanitary Reform Movement. The landmarks for the restatement and consolidation of this movement were the 8th and 9th National Conferences, held in 1986 and 1992, respectively. It has been taking place in the Municipal Health Councils (CMS), whose composition, parity and attributions are guaranteed by a judicial rule ${ }^{(1)}$.

The design of the Brazilian health policy, according to the 1988 constitution, contributes to this construction by attributing to the Ministry of Health the commitment to restructure the care model, based on the health reference framework as a civil right and assuming the organization of increasingly problem-solving, integral and humanized services ${ }^{(2)}$.

In this proposal, the achievement of "health for all" by the year 2010 will not be possible without people's active participation, as the certainty to boast prevention and primary health care depends on them. This participation should also facilitate the coordination of multiple state activities in the health area and permit the construction of aw an holistic health vision to be built ${ }^{(3)}$.

Civil participation is characterized by the replacement of the community or people category by society as the central category. This concept is based on the universalization of social rights, the expansion of the citizenship concept and a new understanding of the State's nature, leading to the definition of the public policy priorities based on a public debate ${ }^{(4)}$. Hence, this participation can be considered as control over the situation itself, through interventions in decisions, initiatives and management that affect the living conditions this situation and projects develop in ${ }^{(5)}$.

Due to these activities, collective involvement has gradually established itself in recent years and has produced political guidelines more and more compatible with reality, so as to guarantee and rationalize material, financial and human resources, while people become increasingly aware of their tasks and responsibilities ${ }^{(6)}$.
Nowadays, after almost two decades of elaboration of this model, the importance of society's active and continuous participation in the actions to be developed seems evident. The implementation of the Family Health Program (PSF), which has been taking place throughout the country, contributes to that and has characteristics that favor the integration between the community and the family health teams, as well as the worker-user relation. In this sense, the introduction of community health agents (ACS) in the teams, the enrollment of users in a defined territory and team work are emphasized.

At family health units, team work favors the community's involvement and participation in the elaboration of a common care project, as the reference population is the recipient of the work developed, assuming an institutional democratization process.

Therefore, the PSF philosophy seeks to achieve a long-term change in the relationship between citizens and the State, promoting the concept of health as a civil right and permitting the subjects' active insertion in quality of life improvement processes through their participation in public policy discussions ${ }^{(6)}$.

Even though this participation is considered relevant, a study about the PSF points to the absence of users as protagonists of their own living and the production of their care, as the team still places the population beyond the scope of the decisions made in their respect ${ }^{(7)}$. The advances in participation and team work have not guaranteed the elaboration of a common care project ${ }^{(4)}$.

The democratic participation in the decisions and actions that define the fate of the Brazilian society is being conquered through hard work, in view of the authoritarian and excluding tradition that has constituted the Brazilian society throughout history ${ }^{(8)}$.

Therefore, acknowledging the relevance of community people's participation in the implementation of a model that aims to improve the quality of life and the difficulties to put it in practice, we try to understand how this participation has been taking place in a PSF, with a view to contributing with data that permit the reflection and development of this elaboration.

\section{PURPOSE}

To check how community participation contributes in the health actions of a Family Health Unit. 


\section{METHODS}

This is a documentary analysis study, using the minutes of team meetings with the community at the Santa Augusta USF, located in Marília.

The Santa Augusta Family Health Unit started its work on April 27, 2003. The coverage area includes 2,348 people. The health team consists of one physician, one nurse, one dentist, one dental aid, two nursing aids, six community agents, one general service aid and, twice a week, one driver. Besides serving as a training area for the first, second and fourth years of the Nursing and Medical Courses at Marília School of Medicine and for the MultiProfessional Family Health Residence at the same institution, the USF offers medical residents and nurses and, as of 2006, dentistry, physical therapy and social service residents. The USF delivers care to the urban and rural population.

In addition to meeting the demand of medical, nursing and dentistry visits, the team performs home visits to people considered at higher risk and with disabling diseases, and activities with hypertensive and diabetes patients groups, soccer, walks, food reeducation, handicraft, hair cut, pre-natal care, growth and development group, and others. Team meetings are held on a weekly basis, when community problems and the team work process are discussed.

Once a month, a community meeting is held with the participation of team professionals, students from Marília School of Medicine (Medicine and Nursing Courses), the chairman of the local community, South Region Board (CONSUL) and other community members. In addition to the team members, approximately four to ten people participate in the meetings. These meetings are recorded in minutes and sent to the PSF Management Team at the Marília Municipal Hygiene and Health Department.

To perform this study, we used the data recorded in minutes of 24 meetings held by the Santa Augusta SPF community, from March 2003 to March 2006.

The result analysis followed the steps of the content analysis technique described by Bardin ${ }^{(9)}$, including: floating reading of each record unit; second reading to separate the record units for classification and to join the raw data contained in these units, representing the content; and categorization per record unit groups of common meaning and elements. This analysis made it possible to joint the minutes of the discussions within four themes: material and human resources, access to more complex health services, adherence of the community to the activities provided by the unit, and health promotion and disease prevention, which are shown as tables with the respective common elements, followed by the descriptive analysis.

\section{RESULTS}

When referring to the themes discussed in the PSF team meetings, whose minutes were analyzed, the theme access to more complex health services, joined in Table 1, shows to be a community concern, due to the limits imposed on health care continuity.

Table 1 - Distribution of subjects, actions and results obtained from the community meetings with the USF regarding the theme: access to more complex health services. Marília, 2006

\begin{tabular}{|c|c|c|}
\hline Theme & Action & Results \\
\hline $\begin{array}{l}\text { Difficulty to schedule } \\
\text { medical specialties. }\end{array}$ & $\begin{array}{l}\text { Communication to the Health } \\
\text { Department management group } \\
\text { of the need to increase the } \\
\text { service offering. }\end{array}$ & $\begin{array}{l}\text { The demand is still } \\
\text { repressed. }\end{array}$ \\
\hline $\begin{array}{l}\text { Delay in the approval of } \\
\text { the tubal ligation process }\end{array}$ & $\begin{array}{l}\text { Clarifications regarding process } \\
\text { evaluation. }\end{array}$ & $\begin{array}{l}\text { Users remain } \\
\text { unsatisfied. }\end{array}$ \\
\hline $\begin{array}{l}\text { Delay to perform a } \\
\text { mammogram }\end{array}$ & $\begin{array}{l}\text { Users were advised to perform } \\
\text { the test in the "mass test" } \\
\text { performed by the Marlia Hospital } \\
\text { das Clinicas. }\end{array}$ & $\begin{array}{l}\text { Most women waiting } \\
\text { underwent the test. }\end{array}$ \\
\hline $\begin{array}{l}\text { Complaint regarding the } \\
\text { quality of care at the } \\
\text { referral hospital. }\end{array}$ & $\begin{array}{l}\text { The management team of the } \\
\text { SMHS performing the dialogue } \\
\text { with the people in charge of the } \\
\text { hospital was informed. }\end{array}$ & $\begin{array}{l}\text { No satisfactory result } \\
\text { has been observed. }\end{array}$ \\
\hline
\end{tabular}

The access to health technologies represents an important aspect to be considered by the sector, as the implementation of the PSF to reorganizing basic care has not been enough to meet the population's needs.

As appointed by Merhy, the PSF must be explored within its limits and incorporated as an integrating technological modality of the complex care net, before it is considered sufficient to solve all problems $^{(10)}$.

The population's difficulty to have access to experts, specific tests and procedures, infringes on constitutional and regulatory principles of the Brazilian health service when it considers "health as a right of all", "integrality", "equity" and "universality".

The difficulty to schedule an appointment with specific experts and tests, as mentioned by the community, shows an important gap in secondary care 
and, consequently, the users are predisposed to health problems, with possible emergency hospitalizations. Additionally, this aspect causes discomfort to the USF team, which is responsible for providing support and explanations about the delay.

When organizing the health system according to the hierarchization and regionalization principle, the idea is to extend coverage and democratize access. However, the basic care net has not been able to become the most important "entrance door", as shown by the high demand in emergency rooms and difficulty to obtain expert services ${ }^{(11)}$. This fact is explained by the lack of resources for health, the misuse of existing resources, in addition to the discrimination in the private sector, exclusively based on the economic criterion, which seeks to guarantee its survival by the creation of health insurances.

Table 2 - Distribution of subjects, actions and results obtained from community meetings with the USF team regarding the theme: community adherence to the activities provided by USF. Marília, 2006

\begin{tabular}{|c|c|c|}
\hline Theme & Action & Results \\
\hline $\begin{array}{l}\text { Lack of adherence to } \\
\text { community meetings }\end{array}$ & $\begin{array}{l}\text { Each person present at the meeting } \\
\text { assumed the responsibility to make } \\
\text { other users aware about } \\
\text { participation in the meetings. } \\
\text { Confection of a banner with the date } \\
\text { and time and placement of the } \\
\text { banner in front of the unit; invitations } \\
\text { were made during USF care and } \\
\text { home visits. Printing and delivery of } \\
\text { invitations to people's homes. }\end{array}$ & $\begin{array}{l}\text { Little improvement in } \\
\text { the adherence. The } \\
\text { users claim disbelief, } \\
\text { tiredness and time } \\
\text { matching with the } \\
\text { soap operas. }\end{array}$ \\
\hline $\begin{array}{l}\text { Lack of adherence to } \\
\text { the group activities } \\
\text { proposed by the unit. }\end{array}$ & $\begin{array}{l}\text { The team started to stimulate } \\
\text { people further, proposed field trips, } \\
\text { such as going to the park; created } \\
\text { activity groups to provide qualify for } \\
\text { work; proposed new handicraft } \\
\text { techniques; and others. }\end{array}$ & $\begin{array}{l}\text { There was an almost } \\
\text { non-significant } \\
\text { increase in } \\
\text { adherence. }\end{array}$ \\
\hline $\begin{array}{l}\text { Lack of adherence to } \\
\text { preventive cenix and } \\
\text { breast cancer test }\end{array}$ & $\begin{array}{l}\text { Orientation performed in the waiting } \\
\text { room; organization of a "special } \\
\text { day" with the sorting of a "beauty } \\
\text { kit". Night time free. }\end{array}$ & $\begin{array}{l}\text { There was an } \\
\text { increase in coverage. }\end{array}$ \\
\hline
\end{tabular}

From the etymological point of view, adherence, from the Latin word adhaesione, means junction, union, approval, agreement, solidarity manifestation, support; it assumes a relation and link. Multi-factorial process is understood as a process structured on the relationship between the care provider and receiver, and involves continuity, perseverance and frequency ${ }^{(12)}$.

Regarding adherence to the community meetings, the small number of people participating in the meetings, around four to ten per meeting, was discussed. Some appoint "tiredness after work" and "the time matching with soap operas" as reasons, in addition to the devaluation of the meeting as a space for problem-solving.
Other promotion and prevention activities proposed by the team have also shown little adherence. In our opinion, this deserves reflection and analysis in terms of effectiveness and adequacy to the population needs. Additionally, these actions need to be broadened, involving intersectoriality, not only to maintain occupation and recreation, but a qualification that permits conquests and perspectives of a better quality of life possible.

In literature, most studies about adherence refer to the process of getting sick and medication treatment, making it difficult to acquire a further understanding of the conditions that may be involved in adherence to promotion and prevention actions like those proposed by the team, as they demand the elaboration of civil awareness.

It is remarkable that citizenship "is not something natural", as it is subject to social and cultural rules. In collective societies like the Brazilian, "the whole prevails over the parts, hierarchy is the basic principle and the relationship is what matters". Therefore, if the subject has no connection with an important person or institution, he/she is treated as inferior $^{(13)}$.

Many times, cases of resistance reveal that people are feeling depreciated or that there does not exist a real dialog between the team and the users' knowledge. It is also emphasized that, in the knowledge confrontation, it is important to consider the complexity articulated in the historical and cultural core that makes this knowledge explicit, thus obtaining an explanation for the difficult adherence ${ }^{(14)}$.

This aspect represents a challenge to healthcare team professionals, who many times adopt authoritarian actions, considering their scientific knowledge as the absolute truth.

Moreover, it seems that the valuation of healing, medication use and the biological aspect as the single way to improve health conditions is present in both the users' and the team's imagination. This fact may also make it more difficult to design measures that aim for promotion and prevention so as to attend to people's needs and, consequently, achieve their adherence.

Therefore, it seems that the lack of population adherence to the healthcare actions, in the search for a better quality of life, is multi-factorial, and the overcoming of strategies must particularly consider bonding, knowledge exchange and respect for the other. 
Despite low community participation, both in team meetings and activities developed at the unit, a great advance is observed in the theme approaches oriented to health promotion and disease prevention, revealing concerns with the development of interventions that go beyond the simple medicalization of life and aim to improve health levels, as observed in Table 3.

The Ottawa letter defines health promotion as "the community qualification process to act in the improvement of quality of life and health, including a higher participation in the control of this process" ${ }^{\prime(15)}$. In this sense, the community meetings have portrayed the theme, as shown in Table 3.

Table 3 - Distribution of subjects, actions and results obtained from the community meetings with the USF team regarding the theme: health promotion and disease prevention, Marília, 2006

\begin{tabular}{|c|c|c|}
\hline Theme & Action & Results \\
\hline Animals in the street & $\begin{array}{l}\text { Guidance regarding the risks } \\
\text { and importance of keeping } \\
\text { animals at home, in the } \\
\text { meetings and during the ACS' } \\
\text { home visits. }\end{array}$ & $\begin{array}{l}\text { There was a decrease of } \\
\text { the number of animals in the } \\
\text { street }\end{array}$ \\
\hline $\begin{array}{l}\text { Garbage spread } \\
\text { throughout the streets } \\
\text { and empty terrains } \\
\text { and lack of recycling. }\end{array}$ & $\begin{array}{l}\text { Request for recyclable } \\
\text { garbage collection cans in } \\
\text { front of the community center; } \\
\text { Community people transmitted } \\
\text { the guidance to the others. }\end{array}$ & $\begin{array}{l}\text { The cans were placed, the } \\
\text { people were guided and the } \\
\text { community itself performs } \\
\text { the supervision. There was } \\
\text { a marked decreased in the } \\
\text { garbage spread. }\end{array}$ \\
\hline $\begin{array}{l}\text { Warm Clothing } \\
\text { Campaign }\end{array}$ & $\begin{array}{l}\text { Placement of banners in the } \\
\text { unit and container for the warm }\end{array}$ & $\begin{array}{l}\text { The wam clothing donated } \\
\text { was distributed to the needy }\end{array}$ \\
\hline & clothing. & population. \\
\hline $\begin{array}{l}\text { Collective } \\
\text { transportation }\end{array}$ & $\begin{array}{l}\text { Discussion about the bad } \\
\text { signalization and drivers' } \\
\text { imprudence. }\end{array}$ & Obstacles and guidance \\
\hline $\begin{array}{l}\text { Community vegetable } \\
\text { garden }\end{array}$ & $\begin{array}{l}\text { Support request from the } \\
\text { Municipal Department of } \\
\text { Agriculture and community } \\
\text { involvement in the acquirement } \\
\text { of seeds and land. }\end{array}$ & $\begin{array}{l}\text { Agriculture technician gave } \\
\text { the orientation; a neighbor of } \\
\text { the unit provided the land } \\
\text { tand companies contributed } \\
\text { with seeds. }\end{array}$ \\
\hline Family Grant & $\begin{array}{l}\text { Clarifications regarding the } \\
\text { criteria for inclusion and } \\
\text { permanence in the program. }\end{array}$ & No questions. \\
\hline $\begin{array}{l}\text { Comprehensive } \\
\text { project by the Traffic } \\
\text { Chamber, providing } \\
\text { resources for } \\
\text { problems related to } \\
\text { the pavement and } \\
\text { signalization of streets. }\end{array}$ & $\begin{array}{l}\text { Report made together with the } \\
\text { community containing the } \\
\text { places requiring } \\
\text { improvements and the } \\
\text { elaboration of the map with the } \\
\text { scoring of difficulties. }\end{array}$ & $\begin{array}{l}\text { Placement of traffic signs, } \\
\text { signalization and obstacles }\end{array}$ \\
\hline "Smile Marlia" week & Community invited. & $\begin{array}{l}\text { Thirty people attended } \\
\text { lectures about oral health } \\
\text { and received gifts. }\end{array}$ \\
\hline World AIDS Day. & $\begin{array}{l}\text { Invitation to participate in the } \\
\text { unit orientation group. }\end{array}$ & $\begin{array}{l}\text { Orientation groups and } \\
\text { distribution of condoms. }\end{array}$ \\
\hline $\begin{array}{l}\text { Occupational accident } \\
\text { prevention week }\end{array}$ & $\begin{array}{l}\text { Invitation to participate in the } \\
\text { unit orientation group }\end{array}$ & $\begin{array}{l}\text { Little community } \\
\text { participation. }\end{array}$ \\
\hline
\end{tabular}

This discussion leads to the belief that the population and the team are getting closer and understand the health concept in a broader sense, including environment, housing, education, work and transportation and others.
There are also signs of a search for intersectorial alliances in favor of the population's health, which focuses on social activities, with the support of healthcare team professionals.

In the team meetings, one of the themes emphasized refers to material and human resources of the unit, as seen in Table 4. The lack of basic drugs was the theme addressed in a number of meetings and the population's dissatisfaction is emphasized, as shown by the great value attributed to this item and the risk that the lack of drugs may represent for the people's health.

Table 4 - Distribution of subjects, actions and results obtained from community meetings with the USF team regarding the theme: material and human resources of the unit. Marília, 2006

\begin{tabular}{|c|c|c|}
\hline Theme & Action & Result \\
\hline $\begin{array}{l}\text { Compliments about } \\
\text { team work }\end{array}$ & $\begin{array}{l}\text { Reading in the team } \\
\text { meeting as an incentive }\end{array}$ & $\begin{array}{l}\text { Team showed to be satisfied and } \\
\text { motivated with the information }\end{array}$ \\
\hline $\begin{array}{l}\text { Community } \\
\text { participation in team } \\
\text { work improvement }\end{array}$ & $\begin{array}{l}\text { Placement of a } \\
\text { suggestions box at the } \\
\text { entry of the unit }\end{array}$ & $\begin{array}{l}\text { The users add suggestions that } \\
\text { are discussed in the team } \\
\text { meetings. }\end{array}$ \\
\hline $\begin{array}{l}\text { Change of team } \\
\text { nembers. }\end{array}$ & $\begin{array}{l}\text { Introduction of the new } \\
\text { physician to the community. } \\
\text { Clarification of the need to } \\
\text { change the psychologist } \\
\text { and social worker. }\end{array}$ & $\begin{array}{l}\text { The population welcomed the } \\
\text { physician and showed good } \\
\text { acceptance. } \\
\text { The participants agreed with the } \\
\text { decision. }\end{array}$ \\
\hline $\begin{array}{l}\text { Lack of basic drugs } \\
\text { at the USF. }\end{array}$ & $\begin{array}{l}\text { The pharmacist in charge } \\
\text { of drugs dispensing at the } \\
\text { Department of Health and } \\
\text { the management group } \\
\text { were contacted. }\end{array}$ & $\begin{array}{l}\text { Some drugs were customized, } \\
\text { others require some time, } \\
\text { causing dissatisfaction and } \\
\text { questioning }\end{array}$ \\
\hline $\begin{array}{l}\text { Inadequacy of the } \\
\text { unit's physical area }\end{array}$ & $\begin{array}{l}\text { Report forwarded to the } \\
\text { Municipal Department. }\end{array}$ & $\begin{array}{l}\text { A change to a wider and more } \\
\text { appropriate space for the care } \\
\text { was provided, after two years } \\
\text { and a half of functioning. }\end{array}$ \\
\hline
\end{tabular}

The continuous crisis in the health sector interferes in the care process and quality in an important way. In spite of the advanced technology existing for health and life preservation and the existence of laws and principles ensuring people's rights, the fact that they are not made effective and the population's suffering are seen as consequences.

The population questioned the inadequacy of the physical area, due to the waiting room's exposure to sunlight in the afternoon, causing discomfort, especially on hot days. The team also appoints discomfort with the size of the meeting room, location and size of the vaccination room, lack of appropriate space to perform inhalation therapy and insufficient number of offices, especially for residents and students visits. After insistent claims of the community together with the team, the site was changed, improving the quality of care and users' satisfaction.

In one of the meetings, satisfaction with the team's receptiveness towards the community, the 
connection and respect developed were indicated. This was discussed in a team meeting, and was considered a motivation and stimulation to work. Additionally, as a way to expand the community's participation in the improvement of team work, a suggestion box was used for the people to contribute to the development of activities. The team collects the suggestions on a weekly basis and discusses them in the meetings. In some cases, the subject is discussed in community meetings.

The team members change, in some cases for personal reasons, and in others due to the managers' needs. This was another theme of discussion with the community. Even though some losses were identified, this need was understood.

The discussions regarding material and human resources seem to reinforce the bond and complicity in the search for alternatives viewing to meet the needs, although they have not always been met.

The organization of the healthcare service structure, even if represents the first step in the search for healthcare quality, guarantees a satisfactory process and results.

\section{FINAL CONSIDERATIONS}

To reach the full exercise of citizenship in the search for worthy living conditions represents a challenge to the healthcare professionals and the community. The great advance in the team meetings with the community, whose minutes were analyzed in this study, represent the elaboration of a democratic and humanitarian system, aimed at improving people's quality of life.

The theme classified from the records of these team-community meetings - "material and human resources", "access to more complex health services", "community adherence to the activities provided by the unit" and "health promotion and disease

\section{REFERENCES}

1. Viana V. A universidade e o controle social do Sistema Único de Saúde no Estado de Pernambuco. Cad Extensão: saúde [periódico online]. [acessado 2005 outubro 11]. Disponível em: http://www.proext.ufpe.br/cadernos/saude/controle.htm

2. Constituição 1988 (BR). Constituição: República Federativa do Brasil.Brasília (DF): Centro Gráfico do Senado Federal; 1988. Art. 196-200, p. 133-4: Da saúde.

3. Briceño-León R. El contexto político de la participación comunitaria en América Latina. Cad Saúde Pública 1998;14(supl2):141-7. prevention" - permit the understanding that the population and the team are seeking new alternatives to make health easier, through the proposals aimed at changing the health/disease concept. To obtain the community's involvement in the actions is an important step to achieve the goals.

Despite the low population participation, different subjects are discussed, promoting coresponsibility among the different actors involved in the process, contributing to improve care quality. Additionally, the meetings have constituted a space for information exchange and search for joint solutions.

In the meetings, complicity, trust and respect have been established between the community and the team, which start to face together the limitations imposed by the current health policy, whose difficulties seem to be more evident for those who are at the system' "front door".

However, the discussions still show characteristics of information sharing with little decision power, as they are still centralized, and the population needs to wait for the right time for decisions about the requests.

The need to advance in this construction is observed, in a way that the population understands the right to act in the co-management of the health system through effective participation in decision processes and claims, more consciously and with more political strength.

We believe that the population must be encouraged and well received by the team to extend its participation, as illustrated by the relevance of the contributions and the reinforcement in the team's decision making, in addition to the bond established.

It is expected that the meetings constitute an increasing participation process in the development of team work and obtain a care that meets the real needs of the population and achieves their actual participation.

4. Crevelim MA. Participação da comunidade na equipe de saúde da família: é possível estabelecer um projeto comum entre trabalhadores e usuários?. Cienc Saúde Coletiva 2005 abril-junho; 10(2):323-31.

5. Rodrigues CG. Democracia $Y$ participation cidadana: em busca de la equidad de nuevos recursos?. Rev Mex Sociol 1994; 3:192-204.

6. Lopes MLS, Almeida MJ. Participação popular e controle social: a experiência de Londrina. Espaço Saúde [periódico online] 2001 junho [acessado 2005 outubro 11]; 2(2). Disponível em : http://www.ccs.uel.br/espaçoparasaude/ v2n2/doc/controle.htm 
7. Matumoto S. Encontros e desencontros entre trabalhadores e usuários na saúde em transformação: um ensaio cartográfico do acolhimento. [Tese] Ribeirão Preto (SP): Escola de Enfermagem de Ribeirão Preto/USP; 2003.

8. Carvalho MCAA. Participação social no Brasil hoje. São Paulo (SP): Polis; 1998.

9. Bardin L. Análise de conteúdo. Lisboa: Edições 70; 1979. 10. Merhy EE. E daí surge o PSF como uma continuidade e um aperfeiçoamento do PACS. Interface Comun Saúde Educ 2001 agosto; 5(9):147-9.

11. Cecílio LCO. Modelos tecno-assistenciais em saúde: da pirâmide ao círculo, uma possibilidade a ser explorada. Cad Saúde Pública 1997 julho-setembro; 13(3):469-78.

12. Silveira LMC, Ribeiro VMB. Grupo de adesão ao tratamento: espaço de "ensinagem" para profissionais de saúde e pacientes. Interface Comunic Saúde Educ 2004 setembro-2005 fevereiro; 9(16):91-104.

13. Da Matta R. A casa e a rua. Rio de Janeiro (RJ): GuanabaraKoogan; 1991.

14. Nunes MO, Trad LB, Almeida BA, Homem CR, Melo MCIC. $O$ agente comunitário de saúde: construção da identidade desse personagem híbrido e polifônico. Cad Saúde Pública 2002 novembro-dezembro; 18(6):1639-46.

15. Ministério da Saúde (BR). Carta de Ottawa. In: Ministério da Saúde (BR). Promoção da Saúde. Brasília: Ministério da Saúde; 2001. p.13-24. 